\title{
Oortuigende milieuskepping en outentieke personasies in dié leesbare historiese roman
}

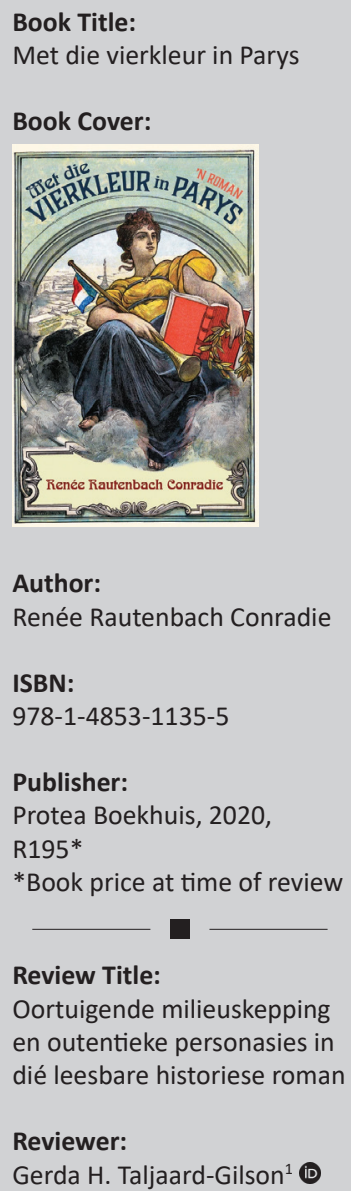

Affiliation:

${ }^{1}$ Department of Afrikaans and Theory of Literature, University of South Africa, Pretoria, South Africa

Corresponding author: Gerda Taljaard-Gilson, gerdagilson@gmail.com

How to cite this book review: Taljaard-Gilson, G.H., 2020, 'Oortuigende milieuskepping en outentieke personasies in dié leesbare historiese roman', Literator 41(1), a1753. https://doi.org/ 10.4102/lit.v41i1.1753

\section{Read online:}

Scan this QR code with your smart phone or mobile device to read online.
Afrikaanse historiese fiksie gee dikwels uitdrukking aan die Afrikaner se soeke na identiteit, sowel as sy of haar gepaardgaande verskeurdheid tussen Europa en Afrika. In Renée Rautenbach Conradie se debuutroman, Met die Vierkleur in Parys, is dit die jong Bolandse argitek Paul Roux wat ' $n$ identiteitskrisis beleef, en nie weet waar hy hoort nie. Hy verwoord sy ontheemding soos volg: 'Ek voel soms of ek twee harte het. Die een hier waar ons voorvaders vandaan kom, en die ander daar waarheen hulle gegaan het' (bl. 63).

Terwyl die Tweede Vryheidsoorlog in Transvaal woed, bevind hy hom in die vooruitstrewende, dekadente wêreldstad Parys, waar hy 'deel geraak het van Montmarte en sy Boheme' (bl. 49). In Parys werk hy aan die Zuid-Afrikaanse Republiek se uitstalling vir die Wêreldskou, kompleet met 'n goudmyn-, pioniershuis- en ossewareplika. Tussendeur vergryp hy hom aan die 'Groen Feeks' (bl. 49), oftewel absint, sowel as aan 'n lorette - dié soort meisie 'wat jy nie aan jou familie voorstel nie' (bl. 62).

Soos Ben Viljoen in Sonja Loots se Sirkusboere (2011), wil Paul Roux graag sy konserwatiewe herkoms en enige gedagte aan die oorlog by die huis soos sy verslete Boereklere van hom afskud. Anders as Ben Viljoen wat dit kon regkry om hom los te maak van die verlede en van sy 'agterlike' vaderland, slaag die hoofkarakter in Met die Vierkleur in Parys egter nie daarin nie. Op verskeie plekke in die roman gee Paul Roux uitdrukking aan sy verdeeldheid tussen Afrika en Europa: Hy voel skuldig 'oor sy verdeelde hart' (bl. 48); hy wens hy 'kan verlore raak in sy nuutgevonde bestaan' (bl. 47); hy voel 'tegelyk verwyderd en skuldig omdat hy Parys geniet terwyl sy land wroeg' (bl. 52-53); en wanneer hy net so lustig saamsing aan 'A la Bastille' as aan 'Kent gij dat volk' (bl. 53), besef hy dat nie enige van dié twee liedere patriotisme by hom aanvuur nie. 'Ek is nie 'n Transvaler nie en ek is nie Frans nie' (bl. 53), merk hy op. Nes die pioniershuis by die uitstalling wat 'lyk soos 'n argiteksoefening wat nêrens hoort nie' (bl. 48), voel Paul nie 'n verbondenheid aan Parys óf Suid-Afrika nie.

So reg in die aard van die historiese roman, is Met die Vierkleur in Parys bevolk met herkenbare historiese figure: Paul Kruger, Claude Debussy, Auguste Rodin en Thomas Edison. Danksy Rautenbach Conradie se oortuigende milieuskepping van 'n vroeë twintigste-eeuse Parys, beweeg hierdie historiese figure moeiteloos saam met die fiktiewe karakters deur dié stad se strate. Verder boekstaaf Rautenbach Conradie, soos Sonja Loots in Sirkusboere (2011) en Willem Anker in Buys (2014), 'n relatief onbekende stuk geskiedenis wat nie dikwels in formele geskiedskrywings voorkom nie.

Terwyl Loots geskryf het oor die Boeregeneraals Ben Viljoen en Piet Cronjé se vernederende deelname aan die Boereoorlogspektakel in Amerika in 1904, en Anker oor die 'Basterkoning' Coenraad de Buys se trek uit die Kaapkolonie in 1815, skryf Rautenbach Conradie oor die Zuid-Afrikaansche Republiek (ZAR) se betrokkenheid in 1900 by die 'grootste skou wat die wêreld nog ooit gesien het' (bl. 38). 'n Hele paar fassinerende besonderhede word verstrek oor die Pavillion de la République Sud-Africaine (bl. 40), onder meer die honderde ruikers wat simpatiekgesinde besoekers by Paul Kruger se borsbeeld gelaat het, en dat die pioniershuis 'die mees besoekte punt van die ganse skou' (bl. 227) was.

Rautenbach Conradie vestig dus ook die aandag op die Franse se simpatieke gesindheid teenoor die Boere tydens die Anglo-Boereoorlog, vernaamlik die Franse kolonel Georges de Villebois-Mareuil 'se heldedood by Boshoff' (bl. 76), toe hy aan die kant van die Boere geveg het. Nog 'n stuk geskiedenis wat hier herwin word, is Paul Kruger se gul ontvangs in Marseille en sy daaropvolgende besoek aan Parys.

Copyright: (c) 2020. The Authors. Licensee: AOSIS. This work is licensed under the Creative Commons Attribution License. 
Alhoewel die Wêreldskou die meeste aandag in Rautenbach Conradie se roman kry, verdwyn die Tweede Vryheidsoorlog geensins in die agtergrond nie. Inteendeel, dit is asof dié oorlog danksy hierdie onderbeklemtoning skerper en rouer voor die gees geroep word, en die onregverdigheid, verskrikking en brutaliteit van die Anglo-Boereoorlog juis daardeur uitgehef word. Met die Vierkleur in Parys bring die leser nader aan dié historiese gebeure as ' $n$ formele geskiedskrywing oor dieselfde feite, want Rautenbach Conradie omskep klinies historiese persone in outentieke mense van vlees en bloed. Dit is veral die figuur van die verswakte Paul Kruger wat in hierdie teks helder voor die leser kom staan: 'Die president is krom, beweeg met moeite, die sakke onder sy oë is swaar en sy baard wit en onversorg' (bl. 230).

Met die Vierkleur in Parys sal byval vind by lesers wat belangstel in Suid-Afrikaanse geskiedenis. Die geskiedenis oor die Wêreldskou in Parys, sowel as oor die AngloBoereoorlog, word op 'n toeganklike, verteerbare en boonop vermaaklike wyse deur Rautenbach Conradie aangebied. Sy skryf vanuit 'n nuwe perspektief oor 'n stuk geskiedenis wat tot dusver nie baie aandag gekry het nie; sodoende argiveer sy dit in die eietydse leser se bewussyn, voordat dit in die vergetelheid verdwyn. 